\title{
ENCOURAGING AND SUSTAINING MANUFACTURING INDUSTRIES IN SOUTHEAST NIGERIA FOR INDUSTRIALIZATION OF AFRICA: A CRITICAL ANALYSIS AND ACTION-BASED EVALUATION
}

\author{
Clementina Uchenna Agbionu \\ Nnamdi Azikiwe University, Awka
}

\begin{abstract}
:
That entrepreneurship remains the bedrock for the development and sustenance of global economies is a truism. That the manufacturing organizations contribute about 80 percent of total GDP of many developed countries is a fact. That manufacturing sub-sector has substantial roles to play in the growth, development and sustenance of the Nigerian economy has been ascertained by many researchers and that the Igbo people in the South-East of Nigeria have a lot of stakes in the entrepreneurial development and sustenance of the Nigerian economy is an established truth. But it is appalling to discover that manufacturing outfits in South-East Nigeria have not been given the attention they deserve to be able to make the needed impact on the growth and sustainable development of the area under study in particular and the nation in general. Based on the above, this paper has sought to examine the relevant the literature to build a sustainable framework for the entrepreneurial growth and development of the Nigerian economy using entrepreneurial organizations in South-East Nigeria as a reference point. The study makes use of descriptive and qualitative content analysis in collecting and analyzing relevant data. The study further builds a framework which, if applied, is expected to practically lead to the sustainable growth and development of the Nigerian economy. Findings from the literature show that entrepreneurship has been widely acclaimed by many developed countries of the world as the wheels on which sustainable economies revolve. Conclusions are drawn based on the findings and recommendations made based on the conclusions.
\end{abstract}

\section{Introduction:}

Growth and development of the nation's economy continue to top the priority list of many nations of the world, developed and developing alike. This stems from the fact that the continued existence of any nation is directly related to its type of economy and the positive and continuous performance of such an economy. Entrepreneurship has continued to remain the bedrock around which sustainable economies revolve and many developed countries of the world such as China, Russia, Indonesia, Belgium and Indonesia, popularly known as the CRIBA countries, owe the present state of their economy to entrepreneurship. Other countries that have equally benefitted from the cream of the wealth of entrepreneurship activities include USA, Europe, Malaysia, to mention but a few. Nigeria is not left out in the desire for and application of entrepreneurship in dealing with its ever-ailing economy, but the big question is not on the issue of adopting a strategy but more on the implementation of such strategy so that it can achieve the desired outcome.

The issue of slow pace of development in many countries of the world, especially Nigeria, has risen to a level where experts begin to ask pertinent questions as to what is exactly the strategy to be adopted in revamping Nigeria's economy. Many proposals have been put forward by successive governments that tried them out but unfortunately a good number of them seem to have failed. Part of the problem of the consistent failures in all these trials stems from the fact that continuity has not been considered a paramount issue in governance in Nigeria. The experience in the Nigerian democratic and political dispensation is that people struggle at all costs to get to the seat of government. Once they get there, they struggle at all costs to see that they start afresh in the developmental agenda, throwing away completely all the strategies the previous government was working on. The resultant effect of these actions has remained that 
the plans, proposals and even on-going projects of the previous governments are left to rot away. This has led to an increase in abandoned projects all over Nigeria. Professor Charles Soludo, the former Governor of Central Bank of Nigeria in his speech at an international conference with the theme, MANAGING A RECESSED ECONOMY - OPTIONS FOR NIGERIA in 2017, lamented the high rate of abandoned projects in Nigeria due to the fact that newly elected officials of government do not continue from where their predecessors stopped. Each successive government would always believe that it has the best solutions to the problem. This usually results in fragmented, uncompleted and totally abandoned projects and this is wasteful, unhealthy and negative to the developmental goals of the nation. Be that as it may, Nigerians, especially those in the academia, would always continue to propose and advance strategies aimed at totally tackling the chronic problem of underdevelopment in Nigeria.

In view of the foregoing, the manufacturing sector has been singled out by this study as a road map to revamping the ailing Nigerian economy. Manufacturing sectors all over the world have been identified and acclaimed as major players in the development agenda of many nations of the world. The manufacturing sector has been playing substantial roles in the growth and development of world economies. Tiffany Mishrahi speaking on the future of the manufacturing industry in the world during the World Economic Forum in 2012, states that" the manufacturing industry is not well understood, yet this industry is of strategic importance to the development of both emerging economies and developed markets". He continues by saying that, "while manufacturing is not the solution to all problems, it is an innovative and high-tech industry that generates many job opportunities". According to him, "manufacturing is no longer what it was in the $19^{\text {th }}$ century; it is not dirty or reserved for blue collar workers". He further opines that people should think of "the high tech and innovative products now manufactured around the world like iPhones or Dyson vacuum cleaners". Indeed, he continues, "modern manufacturing contributes to economic growth and raises both the technological stock and skills of a country". "It is the backbone of any industrialized society and still today can be a strategic advantage for countries worldwide".

The same report continued that he was not disputing the fact that manufacturing has become less strategically important for some countries. To him again, the facts are there - look at the United States for instance: in the 1950s, 30\% of GDP came from manufacturing, compared to $12 \%$ in 2008\%. Nonetheless he asserts that he still believes that in the next 10 years, manufacturing will regain importance and be perceived as the sector that can bring a competitive edge". He also states that "it was already happening: the Obama administration took the decision earlier this year, according to him, to make manufacturing one of the United States' key priorities".

The same thing is applicable to Nigeria. The manufacturing industries in Nigeria were really performing well until some problems that have to do with unstable governance started making the contribution of the manufacturing industry to the national economy dwindle. Since the peak of 7.83 percent in 1982, the performance and contribution of the manufacturing sector as a share of total output in Nigeria has generally declined. Many factors have contributed to the variations in the sector's share through time, some of which attribute the vulnerability of manufacturing to global economic pressures, as well as the effects that policy changes can have on reshaping the sector (Amakon, 2012) quoted by (Agbionu 2017).

Before the emergence of oil and its boom period of the 1970s, the manufacturing sector contributed up to 10 percent to Nigeria's economic development. Items like Coal, Tin, Cement, 
Palm Products etc. dominated the manufacturing sector of the Nigerian economy. They also formed the raw materials for the production of other consumable and non-consumable products of the nation. The production of these commodities grew so much that Nigeria exported them and even went as far as teaching some countries like Malaysia the art of cultivation of some of the raw materials like palm trees in form of nurseries. Other raw materials like cassava, palm oil, rice, cocoa, fruits of various types, and vegetables that had sustained the ever-growing population of Nigeria over the years have been completely overlooked. The consequences of the action caused the sector's contribution to the GDP share to decline. The money from oil was so easy and so quick that nobody was ready to go to suffer in other sectors that take time to mature and generate returns gradually.

The people that dominate the area known and referred to as South-Eastern Nigeria are a popular race commonly known as the Igbo. The area is blessed with a thick population and rather limited land. It is situated, according to their name, in the South-Eastern part of Nigeria. They are generally known for being very hardworking, egalitarian, enterprising, dedicated and committed in whatever they set out to do. They are mainly farmers and active businessmen and natural entrepreneurs. They possess what it takes to develop Nigeria if given the opportunity, but have long been relegated to the background probably because of the experience of the Nigerian Civil War which did not end in their favor. They were referred to as rebels and not given their due and rights in the scheme of things. This development has helped to challenge and delay the development of the Nigerian economy.

In view of the above and more to be discovered later in this paper, this study aims at encouraging the South-Easterners of the Nigerian nation to embrace manufacturing in order to assist in revamping the ailing Nigerian economy.

\section{The Problem:}

Recent developments in the South-East especially Anambra State, necessitated this paper. Statistics and even causal observation that the South-Eastern States have recently been dominated by distributive trade especially petty trading business enterprises in areas of the hospitality industry, petroleum retailing and banking services. Another area that has enjoyed significant increase in recent times is estate development. Cities like Nnewi in Anambra State, Aba in Abia State, and Enugu in Enugu State have many industries some of which were established before now. But in recent times, towns like Awka in Anambra State have not seen the establishment of many manufacturing industries. One begins to wonder what might be the reasons behind this development.

The civil war that occurred in Nigeria was fought mainly within the confines of Eastern Nigeria, from 1967-1970. This was a very bad period for the Igbo. Many young people in this part of the country lost their lives. This period was marked by massive deaths and sickness as a result of underfeeding and denial of basic necessaries of life. Hunger, starvation, deprivation of basic necessities of life, unemployment, poverty and many other ills were the experience of the Igbo people in the South-East. The cause of these negative consequences was outright deprivation by the government at the center. The continuous bad conditions in this region at that time forced many young people to leave the region in droves immediately after the war in search of greener pastures. These traumatic experiences of the civil war made the Igbo psychologically afraid of coming back home shortly after the war. This lingering phobia in the Igbo made a majority of the youths prefer to invest in other places that are not Igbo land. This idea of trying 
to survive first, no matter where, has led them to invest heavily in other areas where they find themselves. An average Igboman no longer finds Igbo land interesting and comfortable.

Other major consequences of the civil war include individualism and self-centredness brought about by the desire to survive the war. When the war broke out, the Igbo worked together to win the war but when the combined efforts of the other regions of what was then known as Nigeria outweighed those of the Igbo, 'things fell apart and the centre could no longer hold'. Everyone was one their own. People started running for their lives. Many people lost their lives in the process. Those who managed to survive took to their heels to any place of abode for security reasons. This individualism among the Igbo still influences their lives and activities in some areas till date. The average Igbo man has no confidence investing in any business with no returns in the immediate or foreseeable future.

Another major reason that discouraged the Igbo especially in Anambra State, from investing in manufacturing is that, because of the same civil war, many Igbo youths did not have the opportunity of going to school. Due to malnutrition, many Igbo children died in large numbers due to a disease known as "Kwashiorkor". An adage says that people do not give what they do not have. It was difficult, if not impossible, for people who were not educated to go into a business they did not know anything about. The best they could do was buying and selling and that has sustained them till date.

The manufacturing sector is a sector that demands a lot of processes before one can go into it and succeed. It is besieged with many risks and demands rigorous planning, organizing, controlling, coordinating many different types of resources especially the human and financial resources to be able to succeed and be sustained. Many big Igbo businessmen were not adequately educated. The best that many of them had was informal training in the form of mentoring and apprenticeship training from informal sources. The fear that many of them have has to do with losing their hard earned money investing in any business they are not conversant with. Their whole idea is to make quick profit with less risk and uncertainty. Their complaint is that if the little money they have managed to save is invested into a business they have little or no knowledge and control over, how on earth will they survive?

All efforts to instil confidence in the Igbo and make them work together as a team have so far not yielded good returns. In view of the above problems and challenges, this paper aims at building a framework that will encourage the Igbo in the South-East of Nigeria to have confidence in investing in manufacturing industries as a road map towards sustainable development in Nigeria. Supporting the above affirmation, Ogbaegbe (2014) stated that 44 years after a traumatic civil war, the Igbo are yet to maximize their full economic potentials, a trend that needs total mental and psychological overhaul to make Igbo land the Dubai of Africa. The same report continued, that it is very possible for the Igbo to achieve this fit because, according to him, his research findings in the past are evident to his assertion, he concluded.

\section{Objectives of the Study:}

This paper aims at building a framework for encouraging the Igbo of South-East Nigeria to invest in the manufacturing sector as a means to sustainable development of the Nigerian economy. Specifically, the paper discusses the following areas that are aimed at achieving the main objective of the study.

- The Manufacturing Sector and the Development of Global Economies

- The Igbo and the development of the Nigerian economy 
- A Framework for Encouraging Manufacturing industries among the Igbo in Nigeria

\section{Review of Relevant Literature:}

\subsection{The Manufacturing Sector and the Development of Global Economies:}

The manufacturing subsector plays a very crucial role in the growth and development of any economy. This was underscored when this statement was made: "The structural transformation of a traditional economy dominated by primary activities into a modern economy where highproductivity activities in manufacturing assumes an important role remains a defining feature of economic development" (Naude, and Szimai: 2016).

In the last few years, probably about 20 years, globalization has drastically changed the manufacturing subsector all over the world. Before the emergence of geographical breakthroughs, manufacturing was carried out locally but with gigantic discoveries in technologies many companies moved their production elsewhere solely based on the reduction in labor costs and costs of other aspects of production, in order to increase revenue. In view of the above, more developed countries lost their manufacturing industries and with a significant share of jobs. In the recent times, however, the situation is gradually reversing due in part to the increase in the labor costs in many emerging economies where Nigeria belongs. In addition, there has also been the issue of revisiting the factors which originally led to relocation.

IT has played a significant role in manufacturing sectors' contribution to the growth and development of economies. During the past, producers handled their production process manually but with the introduction of IT, things have drastically changed as far as production system is concerned especially in many advanced countries of the world. The developing countries also followed suit, though the process is gradual and somewhat expensive. Even as production processes continued IT, many organizations refused to integrate their production processes with the IT-dominated processes with the fear of the uncertainty of the output of the production processes. This was to be expected as many developing countries had not then been conversant with IT and all its components.

Today, things are no longer the way they were in the past. The changes brought about by IT have virtually affected all aspects of people's lives, even in the developing countries. Nigeria's case is not an exception. Part of the problems Nigeria has with IT is accessibility and management. Some of the machines that will do the magic are, in some cases, not affordable by some of these organizations especially in the private sector. Additional to the above problem, is the unavailability of managerial and technical competences needed to operate the machines optimally. Poor maintenance culture is yet another big problem confronting IT solutions in the manufacturing subsector not only in Nigeria but also in many developing countries of the world.

The role of the manufacturing sector in global economies is so overwhelming that Andrew Liveris, Chairman and CEO of Dow Chemical Company, in his recent book titled, Make it in America, supports, with passion, the role that manufacturing production plays in the health of an economy. He stated that today, more than ever, production is vital and that the manufacturing industry can create jobs, economic health and growth at such a level that the service industry will never be able to do. The implication of this statement may be interpreted to mean that not all industries are created equal. 
Though this is the case, the current macro-economic scenario is so much different from what it was in the past years. Business organizations are now being forced by the changes in the environment to adjust their mindsets and other behavioral attitudes in order to move with the changing circumstances in the national and international economies.

On the issue of the contributions of the manufacturing sector, Nimrod (2014) believes that the sector has "contributed more in the growth and development of international economies than meets the ordinary eyes." The claims of the above author are supported by Gruke (2014), in his work, he discusses the strategies these countries have adopted in growing and developing their economies. According to him, "economic development is a continuous thing and for it to be sustained, countries interested must look around and see what worked for their neighboring countries and see how it will work out for them in their unique environment". He states that, for them to succeed, they have "to continuously refine their strategies". In continuation of the claims he made, he states that, "several weeks ago, in 2014, he had the opportunity to travel to Virginia with University of Montana President Royce Engstrom to visit a Rolls Royce jet engine manufacturing site and the Commonwealth Centre for Advanced Manufacturing. He goes on to say that the state-of-the-art facilities embraced manufacturing as jobs for the future point to and provide keen insights on how the public, education and the private sector are working together to build a bright future in Southern Virginia”. His words are quoted as The United States remains the NO. 1 manufacturer in the world, particularly in advanced manufacturing sectors like aerospace and pharmaceuticals - both of which are growth areas". For Missoula-based companies, despite its declining share of overall employment, manufacturing remains a key driver of economic growth. In his opinion and from findings of previous research, manufacturing builds up social capital and wealth, supporting a broad-based middle class and vibrant, healthy communities.

In addition to their above claim, they also claimed from practical experience and research that "the importance of manufacturing extends far beyond the employees, companies and investors directly involved in the industry. It affects everyone". "Manufacturing provides the necessary foundations for an economically sustainable society", they continued. To them the American standards of living depend on the continued success of our manufacturing sector".

The Missoula Economic Partnership believes that the manufacturing sector drives technological innovations - the industry accounts for over two-thirds of all commercial researches and development, which are key to technological innovation and the creation of new, greener products and manufacturing processes.

In conclusion, the body states that one of the take-aways that Engstrom and the author got from their educative visit was that education must align with the needs of industry, and play a vital role in leading and supporting research that advances industrial development. They are of the opinion that the strong partnership between apprenticeship programs, two-year education and traditional higher education is the reason why Virginia was selected by Rolls-Royce for a $\$ 500$ million investment in the state. Their concluding remarks and opinion was that manufacturing is and will remain a critical component of their economy.

To them, from dental instrument makers to awards-winning breweries, and aircraft parts to nutritional supplement producers, Missoula's manufacturing sector is diverse, stable and primed with opportunities. 
They went further to say that companies like Diversified Plastics, CM Manufacturing, Ironwood Manufacturing, as well as the recent additions of Harris Manufacturing ALCOM and LGT Advanced Technologies, continued to thrive and grow in Missoula. They also stated that they would continue to look for the best practices to put in place to grow a vibrant and healthy community.

The World Economic Forum (2012), on the future of the manufacturing industries in international economies states that, as countries face high unemployment rates, they are likely to turn to labour-intensive industries such as manufacturing. For example, in 2911, India revealed its strategic framework - the Twelfth Five-Year Plan - of which manufacturing is a key component. The country will work to increase the share of manufacturing to $25 \%$ of the GDP by 2025 and generate 100 million additional jobs. Similarly, the growing middle class in China, India and Brazil means that there will be a greater need for consumer goods and thus for manufacturing.

They also added that because the world population will continue to grow, consumer expectations are set to boom and supply chain complexity will only increase. In this context, according to them, the manufacturing sector will need to become an innovative, demandoriented industry. Both corporations and government according to them, will work closely to ensure that quality is up to international standards and jobs are created. To them, manufacturing cars, has safety implications that manufacturing clothes does not have.

\subsection{The Manufacturing Sector and the Nigerian Economy:}

The manufacturing sector in Nigeria has had a mixed performance over the years owing to the fluctuations in its contributions to the country's Gross Domestic Product (GDP). Agbionu et al (2017) state that in 1960, the manufacturing sector share of the Nigerian GDP was 4.5 percent rising to 6.9 percent in 1965 and to 7.2 percent in 1970. The same report continued that the manufacturing sector contribution to the GDP stood at 8.3 percent and started to decline in 1993 from 7,2 percent to 6.0 percent in $2000(\mathrm{CBN}, 2003)$. The capacity utilization of the sector fell from 7 percent in 1980 to 42.7 percent in 1986 and 39.0 percent in 1995 . In 1992, the sector in question capacity utilization rose to 40.4 percent and in 1995 collapsed to 29.3 percent. The growth rate of the sector equally rose from 23.6 percent in 1965 to 7.7 percent in 1975 , and fell again drastically to only 6.6 percent in 1980 . The only rise that exceeded 10 percent according to the same report, was recorded at 20.5 percent growth rate in 1985 (CBN, 2000). By 1993, it had fallen to 4.2 percent in 1994. It was recorded 5 percent in general, the industrial sector as a whole grew by 5.2 percent in 1980 to 1986 period and also fell to 0,2 percent in 1996 to 0.72 percent in 1997 (CBN, 2000). Finally, the total manufacturing output in Nigeria was $\$ 6,843,678.59$ million in 2010. It later increased in the following year by $\$ 1,326,277.80$ million or 19.37 percent in 2011 to reach $\$ 8,171,906.39$ million and by $\$ 1,652,610.80$ or 20.22 percent in 2012 to reach a total of $9,824,817.19$ million.

\subsection{The Future of the Manufacturing Sector in Nigeria:}

Manufacturing as a concept involves making use of many resources which can be natural, financial, material, or human to produce goods and services that are needed by a group of people to satisfy identified needs. It must involve the transformation of those resources to make sure that the goals and objectives of both the producer and the consumer are met. From the above analysis, it has been established that the manufacturing sector contributes tremendously to the growth and development of global economies. The same has also been established in the case of Nigeria. Though the sector has not been consistent in the contribution it has been 
making to the growth and development of the Nigerian economy due probably to the uncertainties in the Nigerian polity, this does not mean that that is what it is supposed to be.

Nigeria is well blessed with all the resources it needs to enable the manufacturing sector turn the economy around for good but it has not been able to do so consistently because of many factors, some of which can be environmental in nature. This assertion was supported by Osagie (2004) who states that the prospects of the manufacturing sector in Nigeria providing sustainable economic development, given abundant and varied resource endowment, can support mass production. Developing the Nigerian industrial and manufacturing sector requires the concerted effort of government and the private sector to create an environment that will encourage investment.

Industrialization is, in fact, what Nigeria needs now more than ever to help the manufacturing sector achieve its desired objectives. Industrialization involves the process of transforming an extraction-based economy into a manufacturing-based economy. Nigeria, for some time now, has been operating an extraction-based economy because it has been involved in extraction and exportation of primary products (raw materials). Activities like farming, fishing, mining, animal husbandry, etc have dominated the economy of Nigeria for long. Nigeria even exports some of these raw materials, for instance, palm produce to countries like Malaysia that use these raw materials to produce finished goods and export them back to Nigeria.

In Nigeria, efforts to industrialize the country began after independence with the first national development plan. This plan which took place from 1962 - 1968 focused mainly on import substitution as a means of strengthening the Nigerian manufacturing sector. Other areas of focus of the then policy was increased participation of Nigerians in the control of the economy, expanding the technological base of the country to support industrialization, etc. From that period, the Nigerian economy has experienced many economic and industrialization policies with the most recent being the Vision 20:2020 (Osagie, 2014).

Despite all the efforts made by the Nigerian government to industrialize the economy, Nigeria remains largely underdeveloped and slow to industrialize almost 57 years after her independence.

One may be tempted to ask why this has been the case. Many reasons have been adduced as contributing factors to the ugly situation, some of which have been identified by (Mba 2015) as follows:

Lack of access to credit facilities, overdependence on foreign machines, inadequate raw materials, production of sub-standard goods, illiteracy or inadequate skilled manpower, lack of basic infrastructures, political instability, and militancy. He however suggested improvements in the problems highlighted above.

Writing on the problems and prospects of the manufacturing sector in Nigeria, a document in the grossachieve.com states that this issue will not have been handled well if mention is not made of the effects of the Industrial Revolution of the Western Europe of the $15^{\text {th }}$ and $16^{\text {th }}$ century. According to the paper, the new Encyclopaedia ( $4^{\text {th }}$ edition) $(1075)$ describes the industrial revolution as a term usually applied to the socio-economic changes that marked the transition from a stable agricultural and commercial society to a more machinery-oriented system. 
The paper further stated that agriculture, which has been the major occupation of more than $80 \%$ of the working population in Nigeria, began to suffer from a diminishing role claiming lots of population in manpower.

The paper also stated that a second support for industrialization in developing countries like Nigeria stems from the fact that the economic quart for increase in a wide scope of industrialization both import-substitution and export substitution. The unequal distribution of gains from trade between developed and developing countries is a related justification for the policy of industrialization. South-East Nigeria is made up of an ethnic nationality known and referred to as the Igbo. This ethnic group has a total land area of about 15,800 square miles (about41, 000 square kilometers). The region, according to Ogbaegbe (2014), currently has five states which are Abia, Anambra, Ebonyi, Enugu and Imo States with a population of over 20 million. This region has a common language which is known as Igbo language. A majority of the people in this region are mainly Christian. Their kith and kin could be found in Delta, Rivers, Bayelsa, Edo, Akwa-Ibom and Cross-River States.

\subsection{The Igbo and the development of the Nigerian Economy:}

The Igbo are usually known to be enterprising in nature. The Igbo people are also very intelligent, patient, egalitarian, and resilient with a great deal of intellectual ability. The Igbo people are also entrepreneurial in nature. They are fearless and take a lot of risks to succeed. They are, therefore, known to be industrious, committed and hardworking in anything they decide to do. These qualities give the Igbo race an edge over other races in Nigeria. They struggle to survive in any condition in which they find themselves. Although they are not favoured when it comes to recent trends in the distribution of power as well as the socioeconomic resources of Nigeria by the Nigerian government, the Igbo man is creative, innovative and makes the best out of any condition he finds himself in. These and more of the natural and learned qualities make the Igbo people tick in any environment in which they find themselves. They are great travellers and possess a great quality to integrate and mix with people of different races, cultures, religions, etc. But something has been happening in Igboland in recent times, and that is, that investments by Igbo people tend to favor the distributive sector as opposed to the manufacturing sector. Any right thinking, patriotic Igboman, and even other Nigerians, should be worried about the future of the Igbo race in particular and the Nigerian nation in general. The crux of this paper therefore is to build a framework for encouraging manufacturing industries among the Igbo race in South-East Nigeria.

\section{The Framework for Encouraging Manufacturing Outfit in South-Eastern Nigeria:}

That the manufacturing sector has been the brain behind the development of many strong economies is a fact. That Nigeria has depended mainly on manufacturing sector especially in the area of agriculture in form of extractive industry prior to oil boom era is truism. That SouthEastern Nigeria has been blessed with the potentials to turn the economy of Nigeria around for good is indisputable. Based on the above, creating a successful outcome would be beneficial and a welcome development. The framework for encouraging the manufacturing sector in South-East Nigeria is a task that is vital.

In the words of Ogbaegbe (2014)," fellow Ndi Igbo, Indonesia is a well-balanced economy in which all the major sectors play important roles. Agriculture (including animal husbandry, fishing and forestry) has historically been the dominant activity in terms of both employment and output. We can feed our people, create jobs and export even beyond the shores of Africa 
in large quantities." It is only then, according to him, that Nigerians can talk of any meaningful development. This statement agrees with Adam Smith's statement that any country that cannot boast of feeding its citizens, give them good jobs, good medical facilities, educational facilities and infrastructural facilities, cannot claim that it has developed.

Ogbaegbe reiterates that every state in Igbo land has the ability to produce different agricultural produce and place the region on the map as an agro-based regional economy. He suggests the following measures as ways to solve the problems of agricultural development in Southeast Nigeria:

- Provision of irrigation facilities to encourage all-year farming.

- Well monitored distribution of fertilizers to all farmers in the region

- Adoption of appropriate farming techniques which can help reduce erosion problems

- Distribution of insecticides and pesticides that can help control pests and diseases

- Provision of interest-free Agric loans to encourage young school leavers

- Provision of machineries for hire to encourage youths' involvement and mechanization

- Provision of modern storage facilities like silos and refrigerated vehicles that can help reduce the problem of storage

- Land tenure system should be reformed for easy access to land.

- Rural areas should be provided with facilities such as water, electricity, banks etc to reduce rural -urban migration

- The use of agric extension workers to educate farmers on modern farming techniques and the use of improved seed varieties.

The above framework can be adopted first of all by the South Easterners to tackle the problem of hunger, deprivation, starvation, etc which are ingredients of poverty, and if adequately handled without politicizing it, then, it will pave the way for sustainable growth and development. In fact, the present Governor of Anambra State, Chief Willie Obiano and some other South-East Governors, have inaugurated agricultural programmes aimed at dealing with the identified problems provided it is sustained by incoming administrations after the present ones have ended their tenures.

In addition to the above framework which is first of all tailored to making sure that Nigerian citizens have the basic needs of life, the World Economic Forum of 2012 also stated that the World's complexity and inter-connectivity demand a new type of model and solutions for the industrial sector. This, according to them, is exactly what the Global Agenda Council on Advanced Manufacturing is working on. They established that a new model for manufacturing will not come from one stakeholder but from a multistakeholders' dialogue accounting for all relevant issues affecting the sector, including the rising middle class in emerging economies, innovations, job creation and closing the skills gap, trade policy, supply value chain evolution, environmental impact, and more.

The author, also from experience as a Nigerian, adds to the framework by suggesting that any Igboman who is interested in establishing an entrepreneurial manufacturing industry needs to make sure that:

- He identifies exactly what he intends to do by way of specifically saying" this is the industry I intend to establish."

- The person should make sure that there is a gap in the environment he intends to fill. Establishing industries because others have done so will not suffice. 
- The person must study and understand the business in relation to the knowledge he has acquired in it and the qualities he possesses, both natural and learned, that will enable him do the business

- The person must scan the environment to see if there are existing businesses in that industry he is interested in.

- The person should be sure he has the technical, managerial and financial ability to run such a business. It is possible that he may not have; he may also need to engage someone if he does not have.

- The person needs to have a good business plan and feasibility study that will tell him that the industry is workable.

There are more to the entrepreneurial procedures he needs to make because the list is inexhaustible but he must possess the basic ones and then seek the others outside.

\section{Findings of the Study:}

The major findings from other studies are as follows:

- That Nigeria has, remained underdeveloped after about 57 years of its independence which is not acceptable to many stakeholders

- $\quad$ That the manufacturing sector will play vital roles in ensuring sustainable economic development in many global economies if adequately applied.

- That South-East Nigeria has what it takes to engage in manufacturing industries in order to assist in developing Nigeria, if encouraged.

- That development is a continuous process, therefore, less developed countries should look at developed countries and adopt the strategies that worked for them if such strategies can also work for them.

- That different countries have peculiar problems especially problems that have to do with the uniqueness of their environment. Such countries, especially developing ones, should go back to their basic and fundamental problems and see how to tackle them from within.

- That Nigerian leaders do not continue from where their predecessors stopped especially in the area of projects. Abandoned projects litter all of Nigeria and are an evidence of poor governance and serious signs of underdevelopment.

- That world economic giants such as the Missioulian, an organized body in-charge of developing many manufacturing industries, The Common Wealth Centre for Advanced Manufacturing and The World Economic Forum, all supported the idea that manufacturing industries remain the bedrock of sustainable development for global economies.

\section{Conclusion:}

In this paper, issues concerning the chronic developmental problems of Nigeria and why the Igbo people who are natural entrepreneurs are not playing the roles they are supposed to play have been discussed extensively. The roles of the manufacturing sector in helping to deal with the problem have also been discussed. The Igbo people in South-East Nigeria have also been found to possess the required qualities to turn the Nigerian nation around for good. The basic and fundamental conclusion is that Nigeria should go back to the grassroots and see where it has gone wrong and start from there again to right all the wrongs for the betterment of the nation. 


\section{Recommendations:}

The paper generally recommends as follows:

- That Nigerian leaders should, as a matter of urgency, stop abandoning the projects of their predecessors because continuity helps a lot. The only thing they can do is to amend or restructure them instead of total abandonment. It has not been healthy for Nigerian economic development.

- That Nigeria should look around its neighboring countries to see if there are positive strategies, they have used in developing their economy so as to adopt them.

- That the Igbo in South-East Nigeria should embrace manufacturing as a way to assist in the development of the Nigerian economy.

- That Nigerians, especially the youths, should embrace agriculture instead of abandoning it to the old people in the villages.

- That government should encourage the youths by providing the necessary facilities they need to engage in manufacturing especially in agriculture.

\section{References}

Agbionu, T. C., \& Onwochei, C. (2017). "Trade Liberalization and Performance of Multinational Manufacturing Companies in Nigeria (1990-2015)". International Journal of Innovation Research and Advanced Studies, IJIRAS, VOL.4. ISSUE.4

Amakom, K, (2012). The Concept of Trade Liberalization: A Challenging Policy to develop Economy, Owerri: Faladeco Publishers, Nigeria

Andrew, L. (2014). Make it America. U.S.A. M.

Gruke (2014). "The Contribution of the Manufacturing Sector in the Development of Global Economies" The Missiou Organization, www.missioulian.com.

Mishrahi, T. (2012). The Future of Manufacturing Industry in the Development of Global Economies, www.gobaleconomies.com World Economic Forum (W.E.F.)

Naude \& Szimai. (2016). "The Role of the Manufacturing Industry in the Development of an Economy", www.wikipedia.com

Ogbaegbe, O. (2014). "Harnessing the Rich Economic Potentials of South Eastern Nigeria As Oil Price Drops “www.abusidiqu.com

Osagie. (2014). Prospects and Problems of Manufacturing industries in Nigeria: www.Wikipedia.com

Soludo, C. (2017). Nigeria without Oil Being a paper presented at an International Conference on the theme: MANAGING A RECESSED ECONOMY - OPTIONS FOR NIGERIA: Department of Business Administration, Nnamdi Azikiwe University, Awka, Anambra State, Nigeria.

World Bank. (2002). World Bank Indicator, Washington, D.C: World Bank. 